\title{
BMP A Tool for Assessing Energy Efficient Biogas Production
}

\author{
Yukesh Kannah R, Kavitha S and Rajesh Banu J* \\ Department of Civil Engineering, Regional Centre of Anna University Tirunelveli, India
}

Submission: July 28, 2017; Published: August 21, 2017

*Corresponding author: Rajesh Banu J, Assistant Professor, Department of Civil Engineering, Regional Centre of Anna University Tirunelveli, India, Tel: +91-9444215544; Email: rajeshces@gmail.com

\begin{abstract}
Biomethane Potential (BMP) assay is a key tool to evaluate the biodegradability of organic matter. It is most commonly practices under anaerobic condition and otherwise named as lab scale batch anaerobic digestion test. In BMP assay, series of biochemical reaction takes to degraded and convert organic matter into biogas with the help of methanogenic bacteria. Biogas produced during BMP assay is mainly consist of methane, carbon dioxide and trace amount of other gases. Additionally, it evaluates the quantity of non-biodegradables residue remaining after treatment. It requires minimal labour and operation cost and also easy to monitoring as compared to pilot scale study. Meanwhile it provides more accurate information and which are very useful for design of pilot scale anaerobic digestion (AD) operational parameter for effective bio methane production. Usually, AD process is predominantly suggested for high organic loading rate and it highly reduce the volume of organic matter.
\end{abstract}

Keywords: BMP assay; First order kinetic model; Gompertz equation; Anaerobic digestion; Biomethane

Abbreviations: BMP: Biomethane Potential; OM: Organic Matter; AD: Anaerobic Digestion; MWWT: Municipal Waste Water Treatment; WAS: Waste Activated Sludge

\section{Introduction}

In worldwide, $\mathrm{AD}$ process is highly recommended for stabilisation of organic matter (OM) and effective in generation bio energy in the form of biogas [1]. The composition of biogas generated through $\mathrm{AD}$ process holds $60-65 \%$ of methane $\left(\mathrm{CH}_{4}\right)$, $30-35 \%$ carbon dioxide $\left(\mathrm{CO}_{2}\right)$, and remaining $5 \%$ consist of other gases such as nitrogen $\left(\mathrm{N}_{2}\right)$ hydrogen $\left(\mathrm{H}_{2}\right)$, hydrogen sulphide $\left(\mathrm{H}_{2} \mathrm{~S}\right)$ and ammonia $\left(\mathrm{NH}_{3}\right)$ [2]. BMP assay is an alternative method to assist the specific design criteria for pilot scale AD process. Several researcher have reported that, AD process effective reduce the strength of OM. AD process indirectly help us to protect environmental and reduces impact of greenhouse gases by capturing and utilising the methane as renewable energy source. In general, Municipal Waste Water Treatment (MWWT) plant produce excess amount of waste activated sludge (WAS) during wastewater treatment, which extremely hard to handle and disposal. For safe disposal of generated excess sludge, it account around 50-60\% of operation cost [3]. Similarly in food processing industries is also facing the same problem, because generated waste consist of high $\mathrm{OM}$. AD process was the most successful technology and easy to handle the unavoidable OM before disposal. Since it reduce the certain environmental issues and also upsurge economic benefits from waste $\mathrm{OM}$. AD process takes place in absence of oxygen and in this process the methano genic bacteria plays major role. Anaerobic degradation of WAS comprises of four phases [4]
A. Hydrolysis
B. Acido genesis,
C. Aceto genesis and
D. Methanogenesis

During hydrolysis phase complex WAS is broken down into soluble simple monomers. Hydrolysis is pointed as rate-limiting phase during $\mathrm{AD}$ of WAS and it requires longer solids retention time (SRT) of 25-30 days [5]. To increase the rate of hydrolysis pre treatment of WAS is mandatory. The oretical methane can be calculated, through stoichio metric conversion. Based on chemical oxygen demand (COD), if $1 \mathrm{~g}$ COD reduced is equal to $350 \mathrm{~mL}$ of bio methane produce [6]. Methane production rate can be differ from substrate to substrate and also vary with respect to operational parameters. 


\section{Experimental protocol}

In general, BMP assay was carried to evaluate the degree of bio degradability and to measure the quantity of biogas production from OM. BMP assay was conducted in $300 \mathrm{~mL}$ of Bottle sealed with air tight rubber cork. The bottle was filled with food (substrate): microorganism (inoculum) in the following 1:3 ratio. An aerobically digested sludge or cow rumen was used as a in oculum (active methanogenic bacteria) in the experiment. To maintain alkalinity throughout the experiment $40 \mathrm{mg}$ of $\mathrm{Na} 2 \mathrm{HCO} 3$ was added per litre. Adjusted the $\mathrm{pH}$ value in the range of 6.5 to 7.5. Aluminium foil was wrapped around the bottle in order to avoid light transmission and to maintain darkness inside the bottle. To avoid aerobic respiration, oxygen in the headspace was replaced by purging of nitrogen gas for 3-5mins. The introduced nitrogen will maintain anaerobic environment and it will be helpful for survey of methanogenic bacteria for effective biogas production. Basically, daily biogas production was measured using syringe piston displacement methods Bottles were placed in the incubator at $35 \pm 2{ }^{\circ} \mathrm{C}$ with 90-120rpm shaking speed. Gas Chromatograph is used to estimate the quantity of methane in the biogas.

\section{Steps involved in BMP assay}

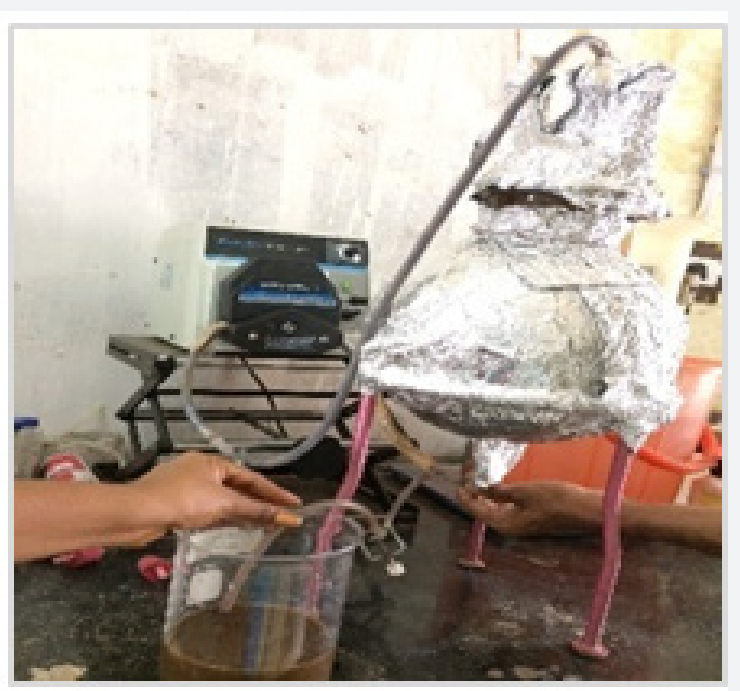

Step 1: Collection of Inoculum from lab scale anaerobic digestors.

A photographic representation of steps involved in BMP assay was illustrated in Figure 1. At step 1, the inoculum (methanogenic bacteria) was collected from lab scale anaerobic digester. The lab scale anaerobic digester was filled with cow rumen and daily high strength wastewater was feed into digester for accumulation of active methanogenic bacteria. In step 2, the BMP bottle was filled with food and microorganism at 1:3 ratios and moreover $40 \mathrm{mg} / \mathrm{L}$ of $\mathrm{Na}_{2} \mathrm{HCO}_{3}$ were added to avoid $\mathrm{pH}$ drop during digestion. In step 3 , the bottle was purged with nitrogen gas to fill the headspace and to remove the oxygen in the bottle. Filled nitrogen gas create feasible anaerobic environment to methanogenic bacteria for effective hydrolysis and convert the OM into biogas. In step 4, air tight seal is provided on neck of BMP bottle using rubber stopper and syringe with needle was introduced on the top of bottle to collect daily biogas. In step 5, aluminium foil is wrapped to the bottle to avoid transmission atmospheric light into the bottle, usually anaerobic digestion takes places under dark condition. In step 6, the BMP bottle was placed in the incubator at $35 \pm 2{ }^{\circ} \mathrm{C}$ with $90-120 \mathrm{rpm}$ of shaking speed to avoid accumulation of OM. In step 7, the syringe piston was displaced to some extent, it show that the biogas were pressurised the piston to displace. Daily the biogas was recorded and then syringe piston was reset to zero. In step 8, Flame test were carried to check the quality of biogas produced. In tip of syringe flame in blue colour, it shows methane present in the biogas.

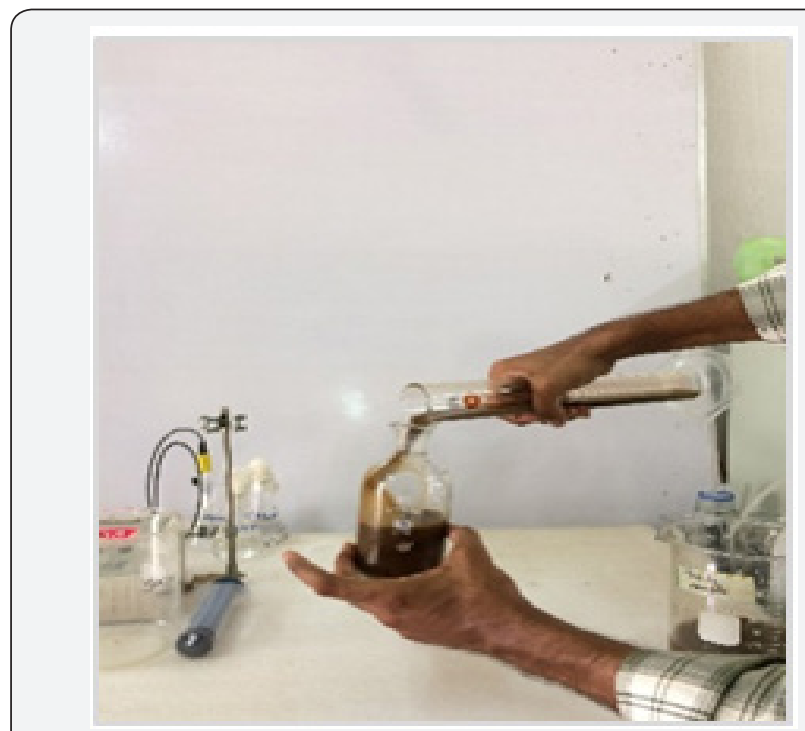

Step 2: Addition of Inoculum and substrate into the bottle.

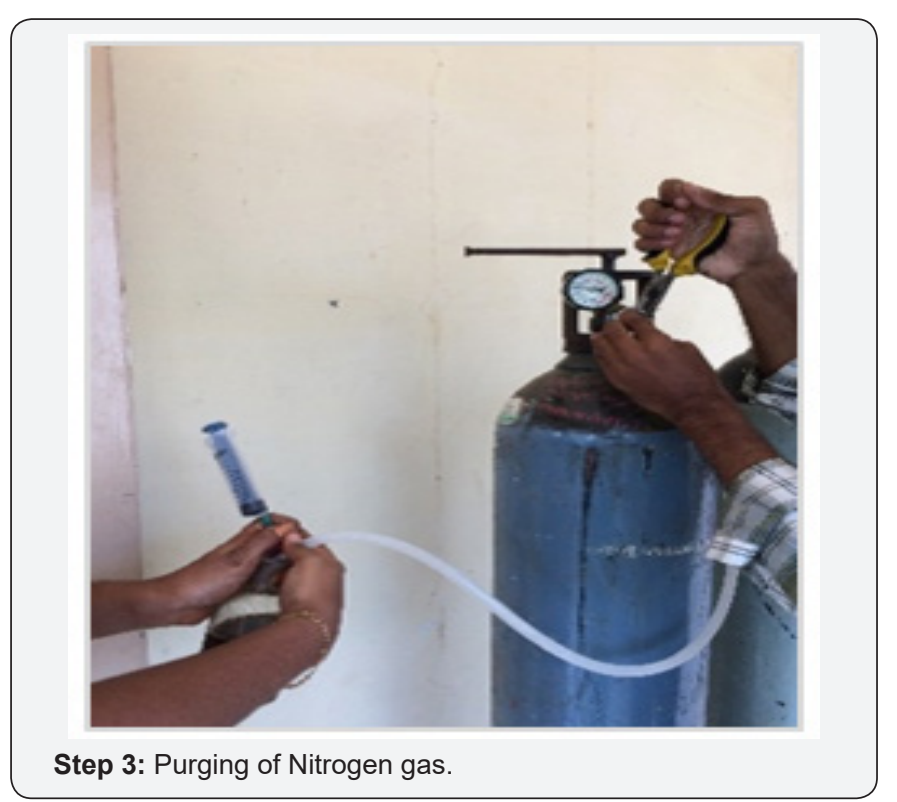




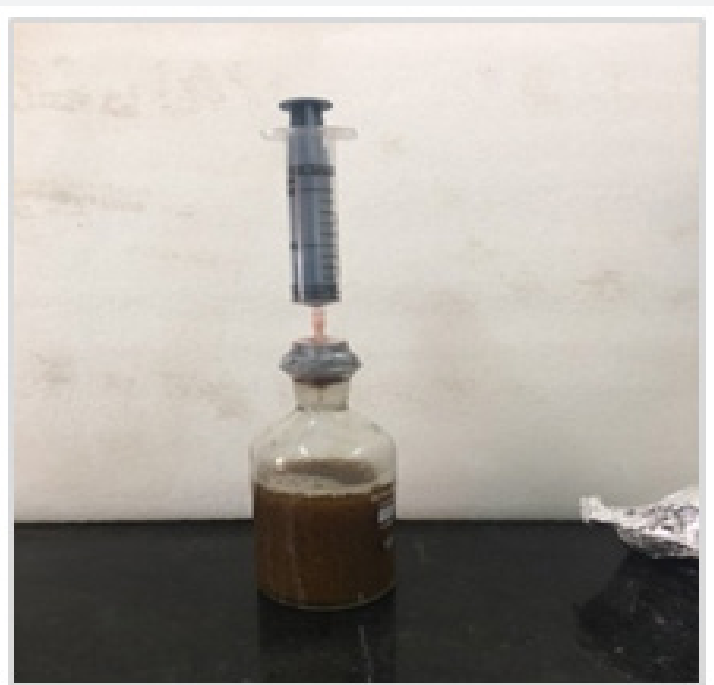

Step 4: Air tight sealed BMP bottle with syringe.

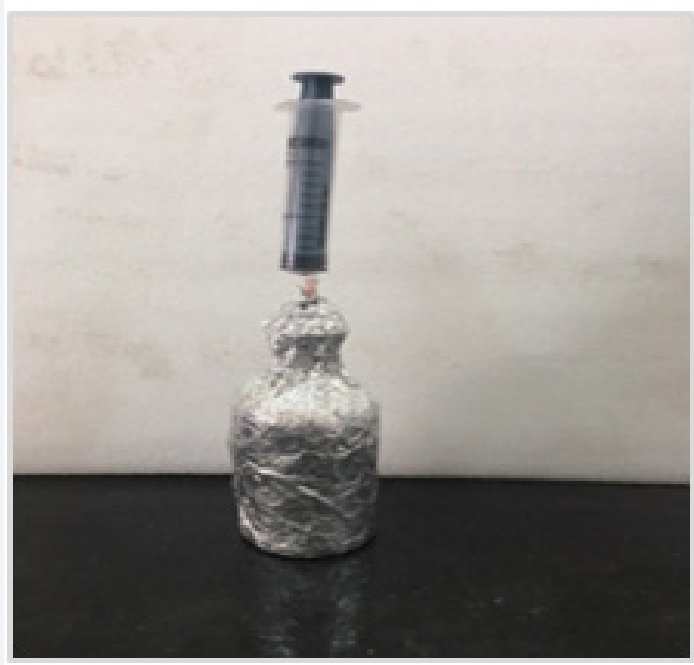

Step 5: Aluminium Foil wrapped around BMP bottle.

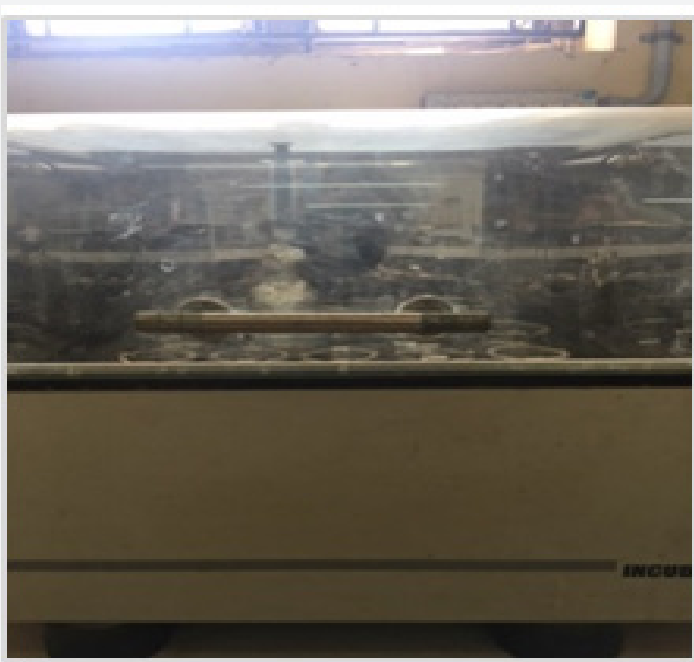

Step 6: BMP Placed in Incubator at $35 \pm 2{ }^{\circ} \mathrm{C}$ at $90-120 \mathrm{rpm}$.

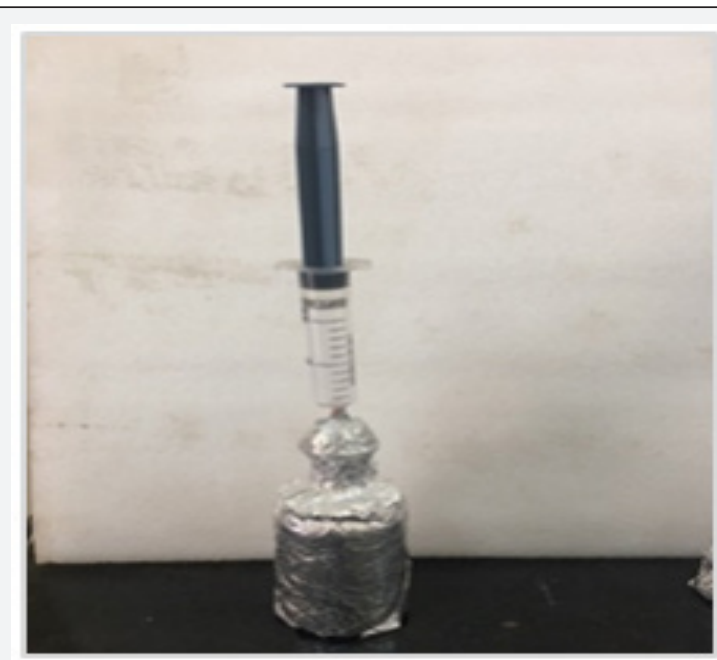

Step 7: Syringe Piston Displaced by pressure created by biogas and reading was recorded.

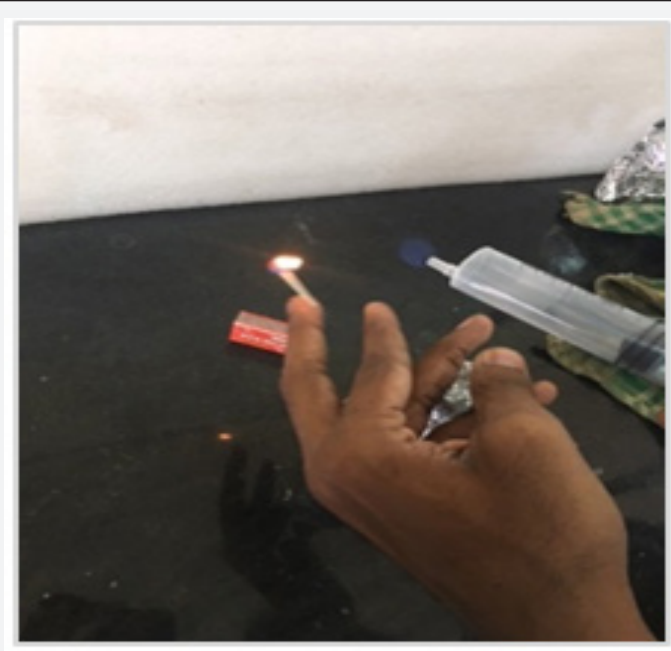

Step 8: Flame test was carried to check methane content in the biogas produced.

\section{Modelling of BMP assay}

In general, two models such as gompertz and first order kinetic model were used to evaluate the amount of biomethane produced in BMP assay. The required equation to estimate the amount of biomethane, was described below.

\section{Gompertz model}

To study the effect of methane production using gompertz model was considered based Kavitha [7] the following equation (2):

$$
B(T)=B^{*} \exp \left[-\exp \left[R_{B} / B^{*} \exp (\lambda-T)+1\right]\right]
$$

\section{Where}

$\mathrm{B}(\mathrm{T})=$ cumulative of biomethane production at time $\mathrm{T}(\mathrm{mL})$,

$\mathrm{B}=$ Biomethane production potential (L/g VS),

$R_{B}=$ Maximal biomethane generation rate (L/g VS .d), 
$\lambda=$ Lag phase (days),

$\mathrm{T}=$ digestion time (days).

The constants $B, R_{B}$, and $\lambda$ were determined by non-linear regression method with the help of Polymath software (Version 6, Shareware company).

\section{First order kinetic model}

To study the effect of methane production using first order kinetics was considered based Kavitha [8]

the following equation:

$$
M(t)=M\left(F_{d}\right) *\left(1-e^{-k^{*} t}\right)
$$

Where

$\mathrm{M}(\mathrm{t})=$ cumulative methane yield at digestion time $\mathrm{t}$ days $(\mathrm{g}$ COD/g COD),

$\mathrm{M}\left(\mathrm{F}_{\mathrm{d}}\right)=$ methane potential of the substrate $(\mathrm{g} \mathrm{COD} / \mathrm{g}$ COD added), and

$\mathrm{k}=$ first order disintegrationrate constant (day-1),

$\mathrm{t}=$ digestion time (days).

The values $\mathrm{M}\left(\mathrm{F}_{\mathrm{d}}\right)$ and $\lambda$ were determined by non-linear regression method with the help of Matlab software (2012a Version).

\section{Factors Influencing BMP Assay}

The bio methane yield may vary from substrate to substrate and also varies with respect to the following operation parameters. Such as $\mathrm{pH}$, temperature, inoculum, food to microorganism $(\mathrm{F} / \mathrm{M})$ ratio, particle size, headspace and mixing was described in below subdivision.

\section{pH}

$\mathrm{pH}$ is the most important factor influences in BMP assay. The $\mathrm{pH}$ value between 7.0 to 7.8 is most favourable for BMP assay and around pH 6.5 to 7.5 is highly recommended for effective biogas production during anaerobic digestion of any substrate. Once the $\mathrm{pH}$ value turns to acidic nature than the methanogenic bacteria get affected or decay by formation of organic acids. Similarly the $\mathrm{pH}$ value turns to alkaline nature then the formation ammonia will reduce the biogas production. In order to maintain $\mathrm{pH}$ value in the range of 6.5 to 7.5 , before starting of experiment $40 \mathrm{mg} / \mathrm{L}$ of sodium bicarbonate was added additionally.

\section{Temperature}

Temperature is another important factor influences in BMP assay. Temperature is directly proportional to biomethane production rate, whereas increases in temperature lead to increase in biogas production during anaerobic digestion process. Usually BMP assay was carried at mesophilic temperature (37 ${ }^{\circ} \mathrm{C}$ ) and thermophilic temperature $\left(55{ }^{\circ} \mathrm{C}\right)$ correspondingly mesophilic and thermophilic bacteria plays a wide role.

\section{Inoculum}

Active methanogenic bacteria are required for effective biome thane generation from feedstock. Anaerobically digested sludge or cow rumen is highly suggested as inoculums, which comprises of several methanogenic bacteria population. For effective biome thane production, the inoculums $\mathrm{pH}$ range should be $7.0 \pm 0.5$.

\section{Food to microorganism $(\mathrm{F} / \mathrm{M})$ ratio}

Food to microorganism is also important factor, it is essential to considered during operation. Food to microorganism ratio less than 0.1 and greater than 1.0 is not recommended for study. If $\mathrm{F} / \mathrm{M}$ ratio is greater than 1.0, excess supply of food (substrate) will upset the process and deplete the activity of methanogenic bacteria. Similarly, if F/M ratio is less than 0.1 , excess supply of microorganism (methanogenic bacteria) will also leads to death phase. The best suitable F/M ratio is the range between $0.3-1.0$.

\section{Particle size}

Particle size will also affect the rate of biogas production during BMP assay. The complex larger size particles require longer retention time to degrade the available particulate organic matter. If the particles size is too small less than $0.1 \mathrm{~cm}$ then the methane yield will be higher.

\section{Headspace}

Headspace is usually consisting of oxygen, which is replaced by purging nitrogen, to maintain anaerobic environment and to avoid aerobic respiration. During anaerobic condition, methanogenic bacteria are more active and efficiently break the organic matter for biogas production. Aerobic respiration affects the activity of methanogenic bacteria and also causes loss in methane production rate.

\section{Mixing}

Mixing is an essential parameter considered during BMP assay. Proper mixing will reduce the accumulation of organic matter and to avoid of extent time to biogas production from substrate. To avoid intermediates formation of volatile fatty acid (VFA) in the digestion medium.

\section{Conclusion}

BMP assay is the essential, before design of pilot scale anaerobic digester for effective biogas production. It acts as optimisation tool for $\mathrm{AD}$ operational parameters. In order to measure the degree of degradation and quantity of biomethane produced in the form of biogas from waste organic matter. AD process reduces environmental impacts by weakening the strength of organic matter and also reduces the effect of greenhouse gas emitted from organic matter. On economic point of view, AD process generate enormous amount alternative renewable fuel source for transportation and power generation. Moreover, treated residue as market value, which are used as 
bio fertiliser for plantation. This mini review gives clearly idea about the BMP assay protocol, steps involved, factor influenced and models used to evaluate the biomethane.

\section{References}

1. Kavitha S, Jayashree C, Adish Kumar S, Ick Tae Yeom, Rajesh Banu J (2014) The enhancement of anaerobic biodegradability of waste activated sludge by surfactant mediated biological pretreatment. Bioresource Technology 168: 159-166.

2. Kwietniewska E, Tys J (2014) Process characteristics, inhibition factors and methane yields of anaerobic digestion process, with particular focus on microalgal biomass fermentation. Renewable and Sustainable Energy Reviews 34: 491-500.

3. Gayathri T, Kavitha S, Adish Kumar S, Kaliappan S, Ick Tae Yeom, et al. (2015) Effect of citric acid induced deflocculation on the ultrasonic pretreatment efficiency of dairy waste activated sludge. Ultrasonics Sonochemistry 22: 333-340.

4. Kavitha S, Saji Pray S, Yogalakshmi KN, Adish Kumar S, Ick Tae Yeom, et al. (2016) Effect of chemo-mechanical disintegration on sludge anaerobic digestion for enhanced biogas production. Environ Sci Pollut Res 23(3): 2402-2414.

5. Uma Rani R, Adish Kumar S, Kaliappan S, Tae Yeom I, Rajesh Banu J (2012) Low temperature thermo-chemical pretreatment of dairy waste activated sludge for anaerobic digestion process. Bioresource Technology 103(1): 415-424.

6. Metcalf, Eddy (2006) INC. Wastewater Engineering: Treatment and Resuse. McGraw Hill series in civil and environmental engineering. $\left(5^{\text {th }}\right.$ edn), McGraw-Hill, New York, USA.

7. Kavitha S, Adish Kumar S, Kaliappan S, Tae Yeom I, Rajesh Banu J (2014) Improving the amenability of municipal waste activated sludge for biological pretreatment by phase-separated sludge disintegration. Bioresour Technol 169: 700-706.

8. Kavitha S, Preethi J, Rajesh Banu J, Tae Yeom I (2017) Low temperature thermo chemical mediated energy and economically efficient biological disintegration of sludge: Simulation and prediction studiesfor anaerobic biodegradation. Chemical Engineering Journal 317: 481-492.

\section{Your next submission with Juniper Publishers} will reach you the below assets

- Quality Editorial service

- Swift Peer Review

- Reprints availability

- E-prints Service

- Manuscript Podcast for convenient understanding

- Global attainment for your research

- Manuscript accessibility in different formats

( Pdf, E-pub, Full Text, Audio)

- Unceasing customer service

Track the below URL for one-step submission https://juniperpublishers.com/online-submission.php 